\title{
Available nutrients status in black soils of Varanasi district of eastern part of Uttar Pradesh
}

\author{
Ashish Rai \\ Department of Soil Science and Agricultural Chemistry, Institute of Agricultural Sciences, \\ Banaras Hindu University, Varanasi, 221005 (Uttar Pradesh), India \\ Surendra Singh* \\ Department of Soil Science and Agricultural Chemistry, Institute of Agricultural Sciences, \\ Banaras Hindu University, Varanasi, 221005 (Uttar Pradesh), India \\ *Corresponding author. E-mail: ssinghssac@yahoo.co.in
}

\begin{abstract}
Soil fertility status of the intensively vegetables growing in black soils of Varanasi (UP), India is not available. Therefore, present study was under-taken to assess the fertility status by collecting 100 surface $(0-15 \mathrm{~cm}$ depth) soil samples using geographical positioning system (GPS). Soil samples were analysed following standard methods. The $\mathrm{pH}$ of the surface soils ranged from 7.3 to 8.4 with a mean of 7.9 indicating alkaline nature of soil. The EC of the soils were normal and ranged from 0.17 to $0.48 \mathrm{dS} \mathrm{m}^{-1}$ with mean value of $0.30 \mathrm{dS} \mathrm{m}^{-1}$. The organic carbon content of the soils ranged from 3 to $9 \mathrm{~g} \mathrm{~kg}^{-1}$ with a mean of $5.8 \mathrm{~g} \mathrm{~kg}^{-1}$. The range (mean) values of available $\mathrm{N}, \mathrm{P}$ and $\mathrm{K}$ were 106 to 291 (184), 8 to 65 (27) and 145 to $358(229) \mathrm{kg} \mathrm{ha}^{-1}$, respectively. The soils were found $99 \%$ low in available $\mathrm{N}$ content and nutrient index rating of available $\mathrm{P}$ was found high. The range (mean) values of $\mathrm{B}, \mathrm{Zn}, \mathrm{Cu}, \mathrm{Fe}$ and $\mathrm{Mn}$ were, 0.11 to $0.53(0.40), 0.38$ to 3.04 (1.08), 0.22 to $1.96(0.79), 2.9$ to $16.40(8.42)$ and 0.68 to $12.64(3.24) \mathrm{mg} \mathrm{kg}^{-1}$ soil, respectively. The available sulphur of the soils ranged from 7 to $33 \mathrm{mg} \mathrm{S} \mathrm{kg}^{-1}$ with mean of $15 \mathrm{mg} \mathrm{S} \mathrm{kg}^{-1}$ soil. Soils were categorised in to low, medium and high status, subsequently $99 \%$ soils were found low in available nitrogen whereas $63 \%$ soil samples were found medium in available phosphorus, and $88 \%$ were medium in available potash. 26,48 and $26 \%$ soils were low, medium and high in S, respectively and the corresponding Figs. for $\mathrm{B}$ were 90,10 and $0 \%$. In case of cationic micronutrients, 7,58 and $35 \%$ soils were low, medium and high in $\mathrm{Zn}$ and the corresponding Figs. for Available Mn were 30, 44 and $26 \%$. Fe was found 6,59 and $35 \%$ in low, medium and high category respectively. There was no copper deficiency found in black soils of Varanasi.
\end{abstract}

Keywords: Black soil, Micronutrients, Primary nutrients, Status

\section{Article Info}

DOI: 10.31018/jans.v10i4.1925 Received: October 15, 2018

Revised: November 19, 2018

Accepted: November 25, 2018

\section{How to Cite}

Rai, A. and Singh, S. (2018). Available nutrients status in black soils of Varanasi district of eastern part of Uttar Pradesh. Journal of Applied and Natural Science, 10(4): 1238-1242

\section{INTRODUCTION}

Black soils of Varanasi district of eastern Uttar Pradesh locally known as Karail are developed in the gangetic alluvium and fall under Vertisols (Chromusterts). The district is located in the IndoGangetic plains and is the most productive region of the country. Imbalanced fertilization is being practiced by farmers in these soils is the root cause of soil health deterioration. Available nutrients in soils play pivotal role in determination of fertility status and sustainable productivity of the soils. Deficiencies of available major, secondary and micronutrients are widespread in soils of Varanasi district of eastern Uttar Pradesh (Tiwari et al., 2003).

Soils of Araziline block of Varanasi district are low in available $\mathrm{N}$, and medium in available $\mathrm{P}$ and $\mathrm{K}$ (Singh et al., 2016a). Conversion of natural ecosystems into agricultural lands for intensive cultivation severely depletes SOC pools (Kumar et al.,
2013). Organic matter and plant residues are major sources of plant-available sulfur in the soil. Decline in deficiency of $\mathrm{Zn}(39.9 \%)$ and increase in Fe deficiency $(14.4 \%)$ have been reported by Shukla et al. (2016) based on the analysis of 1.7 lakh soil samples from different states of India under the All India Co-ordinated Research Project on Micro-and Secondary-Nutrients and Pollutant Elements in Soil and Plants. Widespread sulphur and zinc deficiencies have been reported in the wheat growing alluvial soils of Araziline block in Varanasi district (Singh and Kumar, 2012; Singh et al., 2016b). No systematic effort yet has been made to diagnose the fertility status of primary, secondary and micronutrients in such black soils of the region. The present study was therefore, undertaken to study the available nutrients status of black soils of Varanasi. An attempt was also made to correlate soil available nutrients content with other soil properties vis. a vis. sulphur fractions with their different forms. 
Rai, A. and Singh, S. / J. Appl. \& Nat. Sci. 10 (4): 1238 -1242 (2018)

\section{MATERIALS AND METHODS}

The Varanasi district lies between $25.14^{\circ}$ and $25.23^{\circ} \mathrm{N}$ latitude and $82.56^{\circ}$ and $83.03^{\circ} \mathrm{E}$ longitude, having an area of $1535 \mathrm{~km}^{2}$ comprised of eight Vikas khand (block) with a total of 1,327 villages. The majority of soils of Varanasi fall under alluvial (Inceptisols). Some part of Varanasi district has black soils in Araziline block locally known as Karail (Vertisols).

Soil sampling and analysis: Altogether GPS based 100 surface $(0-15 \mathrm{~cm})$ soil samples were collected randomly from Shahanshahpur village in Araziline block of Varanasi district. The latitude, longitude and elevation at each location were recorded using a hand held global positioning system (eTrex vista, Garmin Ltd.). Sampling site is depicted in Fig. 1. The soil samples were air-dried, processed with wooden pestle and mortar and sieved by $2-\mathrm{mm}$ sieve and reduced it to a $500 \mathrm{~g}$ each and were kept in labeled sample bottles for analysis. The soil samples were analyzed for soil reaction $(\mathrm{pH})$ and electrical conductivity (EC) in 1:2.5 soil: water suspension (Jackson 1973); organic carbon by Walkley and Black (1934); available $\mathrm{N}$ by alkaline potassium permanganate (Subbiah and Asija 1956); available $\mathrm{P}$ by $\mathrm{NaHCO}_{3}$-extractable $\mathrm{P}$ (Olsen et al. 1954), available $\mathrm{K}$ by ammonium acetate-extractable K (Hanway and Heidel 1952); available sulphur by $0.15 \% \mathrm{CaCl}_{2}$ (Williams and Steinbergs 1959) using turbidimetric method (Chesnin and Yien 1951); boron in soils was extracted by hot water (1:2 soil: water ratio, heating time $5 \mathrm{~min}$ ) (Gupta 1967) and concentrations in extracts were analyzed using Azomethine- $\mathrm{H}$ with UV-Visible spectrophotometer. DTPA-extractable micronutrients (Lindsay and Norvell 1978) using atomic absorption spectrophotometer (Agilent 240FS AA).

Nutrient index $(\mathrm{NI})$ was calculated according to the relationship given below.

$$
\text { Nutrient index }=\frac{\mathrm{NI}+2 \mathrm{Nm}+3 \mathrm{Nh}}{\mathrm{NI}+\mathrm{Nm}+\mathrm{Nh}}
$$

.Eq. 1.

Where, $\mathrm{NI}, \mathrm{Nm}$ and $\mathrm{Nh}$ are the number of soil samples falling in category of low, medium and high status and given weightage of 1,2 and 3 , respectively.

\section{RESULTS AND DISCUSSION}

Soil properties: Results showed that soils varied widely in their soil properties and content of avaialble nutrients (Table 1). The $\mathrm{pH}$ of the surface soils of Shahanshahpur village in Araziline block of Varanasi district ranged from 7.3 to 8.4 with a mean of 7.9 indicating alkaline nature of soil. Most of the soils fall under slightly alkaline to alkaline category. The EC of the soils were normal and it ranged from 0.17 to $0.48 \mathrm{dSm}^{-1}$ with mean of $0.30 \mathrm{dSm}^{-1}$. The organic carbon content of the
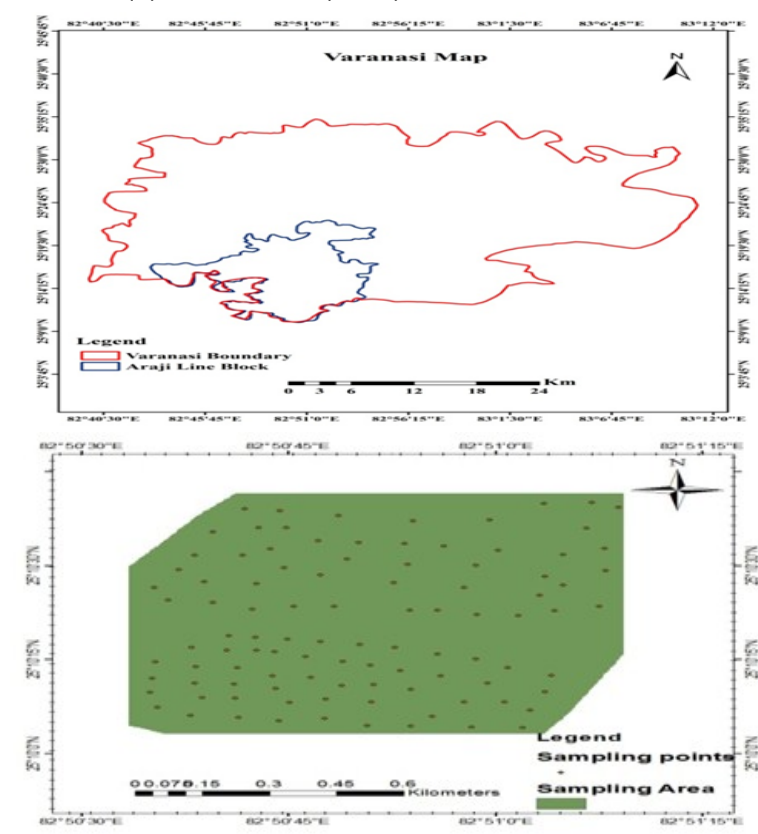

Fig. 1. Sampling site of the study area, Shahanshahpur village in Araziline block of Varanasi district.

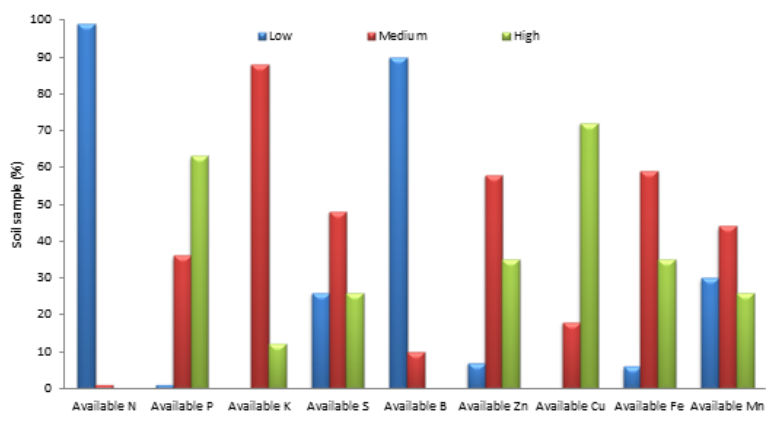

Fig. 2. Nutrients status of black soil of Varanasi.

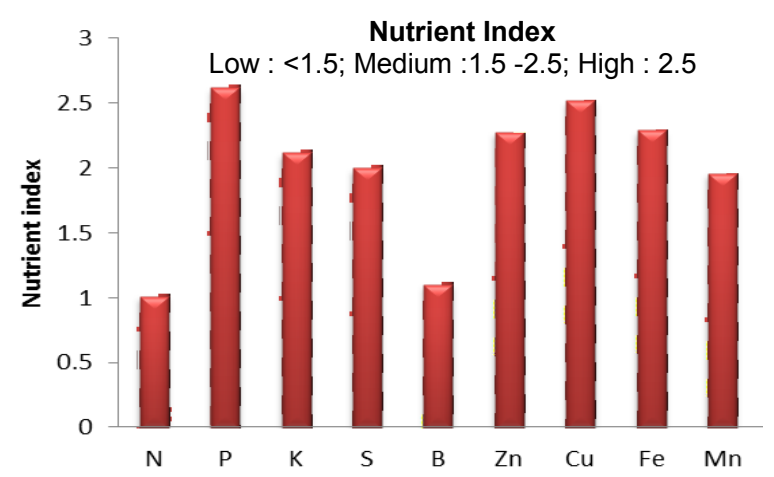

Fig. 3. Nutrient Index of macro and micronutrients of black soils.

soils ranged from 3 to $9 \mathrm{~g} \mathrm{~kg}^{-1}$ with a mean of 5.8 $\mathrm{g} \mathrm{kg}^{-1}$ soil. It was observed that $33 \%$ soils were rated to be low, $53 \%$ medium and $14 \%$ high in organic carbon content. The soils were deficient in content of organic carbon, this may probably attributed due to low adoption of crop residue recycling and organic manure addition practices coupled with rapid decomposition and mineralization 
Rai, A. and Singh, S. / J. Appl. \& Nat. Sci. 10 (4): 1238 -1242 (2018)

Table 1. Summary statistics\# for soil properties and extractable sulphur concentrations in Black soils.

\begin{tabular}{lllllll}
\hline Parameter & Min & Max & Mean & CV (\%) & Skew $^{*}$ & Kurt $^{* *}$ \\
\hline $\mathrm{pH}$ & 7.30 & 8.40 & $7.9( \pm 0.02)$ & 2.42 & -0.22 & 0.49 \\
$\mathrm{EC}\left(\mathrm{dSm}^{-1}\right)$ & 0.17 & 0.48 & $0.30( \pm 0.01)$ & 22.54 & 0.14 & -0.79 \\
Organic Carbon $\left(\mathrm{g} \mathrm{kg}^{-1}\right)$ & 3.0 & 9.0 & $5.8( \pm 0.01)$ & 24.09 & 0.19 & -0.49 \\
Available N $\left(\mathrm{kg} \mathrm{ha}^{-1}\right)$ & 106 & 291 & $184( \pm 3.85)$ & 20.87 & 0.17 & -0.15 \\
Available P $\left(\mathrm{kg} \mathrm{ha}^{-1}\right)$ & 8 & 65 & $27.24( \pm 1.41)$ & 51.60 & 1.22 & 0.72 \\
Available K $\left(\mathrm{kg} \mathrm{ha}^{-1}\right)$ & 145 & 358 & $229( \pm 4.74)$ & 20.68 & 0.39 & -0.62 \\
Available S $\left(\mathrm{mg} \mathrm{kg}^{-1}\right)$ & 7 & 33 & $15.52( \pm 0.60)$ & 38.32 & 0.67 & -0.38 \\
Available B $\left(\mathrm{mg} \mathrm{kg}^{-1}\right)$ & 0.11 & 0.53 & $0.40( \pm 0.01)$ & 19.71 & -1.03 & 1.95 \\
Available Zn $\left(\mathrm{mg} \mathrm{kg}^{-1}\right)$ & 0.38 & 3.04 & $1.08( \pm 0.04)$ & 37.76 & 1.56 & 4.97 \\
Available Cu $\left(\mathrm{mg} \mathrm{kg}^{-1}\right)$ & 0.22 & 1.96 & $0.79( \pm 0.04)$ & 46.29 & 0.94 & 0.68 \\
Available Fe $\left(\mathrm{mg} \mathrm{kg}^{-1}\right)$ & 2.90 & 16.40 & $8.42( \pm 0.28)$ & 32.83 & 0.59 & 0.07 \\
Available Mn $\left(\mathrm{mg} \mathrm{kg}^{-1}\right)$ & 0.68 & 12.64 & $3.24( \pm 0.19)$ & 59.89 & 1.69 & 4.70 \\
\hline
\end{tabular}

\#Min: Minimum, Max: Maximum, CV: Coefficient of variation, Skew*: Skewness, Kurt**: Kurtosis

Table 2. Correlation amongst soil properties.

\begin{tabular}{|c|c|c|c|c|c|c|c|c|c|c|c|c|}
\hline $\begin{array}{l}\text { Soil pa- } \\
\text { rameter }\end{array}$ & $\mathrm{pH}$ & EC & OC & $\mathbf{N}$ & $\mathbf{P}$ & $\mathrm{K}$ & $\mathbf{S}$ & B & $\mathbf{Z n}$ & $\mathrm{Cu}$ & $\mathrm{Fe}$ & $\begin{array}{l}\mathrm{M} \\
\mathrm{n}\end{array}$ \\
\hline $\mathrm{pH}$ & 1 & & & & & & & & & & & \\
\hline EC & -0.135 & 1 & & & & & & & & & & \\
\hline $\mathrm{OC}$ & -0.152 & 0.049 & 1 & & & & & & & & & \\
\hline $\mathrm{N}$ & $-0.241^{*}$ & 0.069 & $0.772^{\star \star}$ & 1 & & & & & & & & \\
\hline $\mathrm{P}$ & -0.064 & 0.051 & -0.194 & -0.106 & 1 & & & & & & & \\
\hline K & $-0.247^{*}$ & 0.017 & $0.631^{\text {** }}$ & $0.739^{* *}$ & $-0.270^{\star *}$ & 1 & & & & & & \\
\hline$S$ & -0.009 & 0.081 & 0.046 & -0.010 & -0.138 & -0.011 & 1 & & & & & \\
\hline$B$ & -0.100 & -0.005 & -0.086 & 0.022 & 0.165 & -0.081 & 0.114 & 1 & & & & \\
\hline $\mathrm{Zn}$ & -0.154 & 0.102 & 0.165 & 0.158 & $0.432^{* *}$ & 0.093 & -0.120 & 0.087 & 1 & & & \\
\hline $\mathrm{Cu}$ & 0.183 & -0.081 & -0.006 & -0.097 & 0.131 & -0.099 & -0.050 & $-0.327^{* *}$ & 0.128 & 1 & & \\
\hline $\mathrm{Fe}$ & -0.111 & 0.128 & $0.235^{*}$ & $0.324^{* *}$ & -0.021 & $0.274^{\star *}$ & -0.059 & -0.077 & 0.129 & 0.032 & 1 & \\
\hline $\mathrm{Mn}$ & 0.015 & 0.092 & -0.154 & -0.161 & $0.458^{* *}$ & -0.136 & $-0.245^{*}$ & 0.021 & 0.096 & 0.093 & -0.100 & 1 \\
\hline
\end{tabular}

${ }^{*}$ and ${ }^{* *}$ denote significant at $5 \%$ and $1 \%$ level, respectively

of organic matter in sub-tropical climatic condition. Highest amount of crop residue burning, among the Indian states, was reported in Uttar Pradesh (Jain et al., 2014) which may be the probable reason of low organic carbon in the soils. Descriptive statistics and Pearson's correlation coefficients analysis were done for the soil properties and obtained using Analysis tool Pak in excel sheet.

Available major nutrients: Available $\mathrm{N}$ in soils ranged from 106 to $291 \mathrm{~kg} \mathrm{ha}^{-1}$ with a mean value of $184 \mathrm{~kg} \mathrm{ha}^{-1}$ (Table 1), 99\% of the soils being low in available $\mathrm{N}$ content with $1 \%$ in medium category (Fig. 1). As regards to the nutrient index of $\mathrm{N}$, it was 1.01 which falls under low category (Fig. 3 ). The mean available $\mathrm{N}$ content of the soils were $184 \mathrm{~kg} \mathrm{ha}^{-1}$ and grouped in low category of nutrient index (<1.5) (Fig. 3). Poor content of organic carbon and limited addition of $\mathrm{N}$ through externl sources have made these soils poor in available $\mathrm{N}$ content. The available $P$ ranged between 8 to 65 $\mathrm{kg} \mathrm{ha}^{-1}$ with a mean of $27 \mathrm{~kg} \mathrm{ha}^{-1}$ (Table 1) and 01 , 36 and $63 \%$ of the soils had rated as low, medium and high contents, respectively (Fig. 2). The nutrient index rating of available $P$ was high (Fig. 3 ) and it has been observed that most of the soils tested were in medium to high category. It was further noted that build-up of available $P$ was far beyond the level of high available $P$ rating $(>25 \mathrm{~kg}$ $\left.\mathrm{ha}^{-1}\right)$. It is needed to reassess the crop requirements of $P$ to revise present rating of available $P$ in order to derive full benefit of $P$ build-up in soil. The exchangeable $\mathrm{K}$ status in surface soils ranged from 145 to $358 \mathrm{~kg} \mathrm{ha}^{-1}$ with a mean of $229 \mathrm{~kg} \mathrm{ha}^{-1}$ (Table 1). The samples under low, medium and high categories were 00,88 and $12 \%$, respectively (Fig. 2). Most of the soil samples were tested as medium in available $\mathrm{K}$ (Table 1 ) and nutrient index for exchangeable $\mathrm{K}$ was found medium (Fig. 3). Soils of Indo-Gangetic plains are inherited in available $\mathrm{K}$ content due to presence of micaceous or illitic minerals, however, we observed that due to intensive cropping and limited use of the Kfertilizers by the farmers, the level of available $\mathrm{K}$ in soils is declining which needs to be addressed.

Available sulphur: Nutrient index and sulphur availability index are depicted in Fig. 3 and 2 respectively. The available $S$ status in surface soils ranged from 7 to $33 \mathrm{mg} \mathrm{kg}^{-1}$ with a mean of 15.52 $\mathrm{mg} \mathrm{kg}^{-1}$ (Table 1). Of the total samples 26, 48 and $26 \%$ samples were falled under low, medium and high categories, respectively (Fig. 2). Most of the soil samples were tested as medium in available $S$ and the nutrient index for available $S$ was medium (Fig. 3).

Available micronutrients: The available B status in surface soils ranged from 0.11 to $0.53 \mathrm{mg} \mathrm{kg}^{-1}$ with a mean of $0.40 \mathrm{mg} \mathrm{kg}^{-1}$ (Table 1). The samples under low and medium categories were found 90 and $1 \%$, respectively (Fig. 2) and there had no soil sample which could fall under high category. 
Most of the soil samples were tested as low in available $B$ (Table 1) and the nutrient index for available B was found low (Fig. 3). The DTPAextractable $\mathrm{Zn}$ content in surface soils ranged from 0.38 to 3.04 with a mean of $1.08 \mathrm{mg} \mathrm{kg}^{-1}$ soil (Table 1). Here, we observed that $58 \%$ soils were medium ( $<0.5 \mathrm{mg} \mathrm{kg}^{-1}$ ) in $\mathrm{Zn}$ content (Fig. 2) and nutrient index of available $\mathrm{Zn}$ was also found in medium category (Fig. 3). The DTPA-extractable Cu content in soils ranged from 0.22 to 1.96 with a mean of $0.79 \mathrm{mg} \mathrm{kg}^{-1}$ soil (Table 1). Almost all the soils were sufficient $\left(>0.2 \mathrm{mg} \mathrm{kg}^{-1}\right.$ soil) in DTPAextractable $\mathrm{Cu}$, however, $18 \%$ soils were medium (Fig. 2) with high nutrient index (Fig. 3). The DTPA-extractable Fe content in soils ranged from 2.9 to 16.40 with a mean of $8.42 \mathrm{mg} \mathrm{kg}^{-1}$ soil (Table 1). It was observed that almost all the soils were moderate to sufficient in DTPA-extractable $\mathrm{Fe}$, however, $6 \%$ soils were low (Fig. 2) with medium nutrient index (Fig. 3). The DTPA-extractable Mn content in soils ranged from 0.68 to 12.64 with a mean of $3.24 \mathrm{mg} \mathrm{kg}^{-1}$ soil (Table 1). Soils were categorized and found 30, 44 and 26 percent in low, medium and high category, respectively (Fig. 2) with medium nutrient index (Fig. 3). This block being in close proximity to the Varanasi city are intensively vegetables cultivated belt which may be interpreted as a probable reason for high degree of $B$ and $M n$ deficiency in these soils. Some extent of DTPA extractable Mn deficiency in these soils might be due to fact that under alkaline conditions, the Mn cation is changed largely to their oxides or hydroxides and there by lower the availability of Mn in soils (Meena et al. 2006). Hot water soluble $B$ was found mostly deficient in all the soils which show the avoidance of the boron containing fertilizers in this area.

Correlation study: Correlation studies (Table 2) indicated positive and significant correlation of available $S$ with $P\left(r=0.968^{* *}\right), B\left(r=0.207^{* *}\right), Z n$ $\left(r=0.355^{\star *}\right), \operatorname{Mn}(r=0.375)$ and SAI $\left(r=0.995^{\star *}\right)$ but negatively with $K(r=-0.293)$. These observations corroborate the finding of Das et al. (2011) who studied interrelationship of forms of sulphur with its availability indices and soil properties in entisols of Assam and observation is in close agreement with that of Borkotoki and Das (2008). Soil $\mathrm{pH}$ was negatively correlated with the available $N\left(r=-0.241^{*}\right)$ and available $K\left(r=-0.247^{*}\right)$. Organic carbon had positive and significant correlation with available $\mathrm{N}\left(\mathrm{r}=0.772^{*}\right), \mathrm{K}\left(\mathrm{r}=0.631^{*}\right)$ and $\mathrm{Fe}\left(r=0.235^{\star}\right)$ which shows the effectiveness of the organic matter for the availability of these nutrients in the soil. It is a matter of fact that these three nutrients are closely related with organic matter and their mineralization by microorgaisms in soils. The soils in this study were under conventional tillage and this may have compromised the amounts of $\mathrm{C}$ stored. Soil organic matter stabilization has been generally attributed to physical pro- tection from decomposition by soil microoraganisms (Hassink 1992; Pulleman et al. 2005) and the protective action by clays (Denef and Six 2005). Soils had weakly transformed organic matter which could be the reason of no significant relationship of organic carbon with available S. However, in the organo-minerals horizons where organic matter is humified, it clearly appears that the mineralization and the humification of the original organic matter lead to a preferential loss of carbon. Available $\mathrm{N}$ was positive and significantly correlated with the available $\mathrm{K}\left(r=0.739^{* *}\right)$ and $\mathrm{Fe}$ $\left(r=0.324^{* *}\right)$. Available $P$ was positive and significantly correlated with available $\mathrm{Zn}\left(r=0.432^{* *}\right)$ and $\mathrm{Mn}\left(r=0.458^{* *}\right)$ but negatively with $\mathrm{K}$ ($\left.0.270^{* *}\right)$. Available $K$ was positively and significantly correlated with the available $\mathrm{Fe}(r=$ $\left.0.274^{* *}\right)$. Hot water soluble $B$ was negatively correlated with available $\mathrm{Cu}(r=-0.327)$.

\section{Conclusion}

It is concluded from the present investigation that the intensively vegetables cultivated black soils of Varanasi showed low in available N (99), S (26) and B (90) percent. Therefore, judicious application of $N, S$ and $B$ fertilizers are necessary for sustaining crop productivity in the region. In addition to this, $\mathrm{Mn}$ deficiency (30\%) is also emerging; therefore, application of $\mathrm{Mn}$ containing fertilizer is advised in soils.

\section{ACKNOWLEDGEMENTS}

Authors are highly grateful to Department of Soil Science and Agricultural Chemistry, Institute of Agricultural Sciences, Banaras Hindu University, Varanasi-221005 for providing necessary assistance and facilities during research work.

\section{REFERENCES}

1. Borkotoki, B. and Das, K.N. (2008). Forms of sulphur and their relationship with soil properties in Entisols, Inceptisols and Alfisols of Assam. Journal of the Indian Society of Soil Science. 56:186-191.

2. Chesnin, L. and Yien, C.H. (1951). Turbidimetric determination of available sulphate. Soil Science Society of America Proceedings. 15:149-151.

3. Das, K.N., Basumatary, A. and Borkotoki, B. (2011). Interrelationship of forms of sulphur with its availability indices and soil properties in Entisols of Assam. Journal of the Indian Society of Soil Science. 59:134140

4. Denef, K., and Six, J. (2005). Clay mineralogy determines the importance of biological versus abiotic processes of macroaggregate formation and stabilization. European Journl of Soil Science. 56:469-479.

5. Gupta, U.C. (1967). A simplified procedure for determining hot-water-soluble boron in Podzol soils. Soil Science. 103:424-428.

6. Hanway. J. and Heidel, H. (1952). Soil analysis methods used in lowa State College soil testing laboratory. lowa State College Agricultural Bulletin. 57:1-13.

7. Hassink, J. (1992). Effects of soil texture and struc- 
ture on carbon and nitrogen mineralization in grassland soil. Biol Fertil Soil. 14:126-134.

8. Jackson, M.L. (1973). Soil Chemical Analysis.Prentice Hall of India (Pvt.) Ltd., New Delhi.

9. Jain, N., Bhatia, A. and Pathak, H. (2014) Emission of Air Pollutants from Crop Residue Burning in India. Aerosol and Air Quality Research, 14: 422-430, doi: 10.4209/aaqr.2013.01.0031.

10.Kumar, R., Rawat, K.S., Singh, J., Singh, A. and Rai, A. (2013). Soil aggregation dynamics and carbon sequestration. Journal of Applied and Natural Science. 5(1):250-267.

11.Lindsay, W.L. and Norvell, W.A. (1978). Development of DTPA soil test for zinc, iron, manganese and copper. Soil Science Society of America Journal. 42:421-428.

12.Meena, H.B., Sharma, R.P. and Rawat, U.S. (2006). Status of macro and micronutrients in some soils of Tonk district of Rajasthan. Journal of the Indian Society of Soil Science, 54(4):508-512.

13.Olsen, S.R., Cole, C.V., Watanable, F.S. and Dean, L.A. (1945). Estimation of available phosphorus in soil by extraction with sodium bicarbonate. Circular 939 United States Department of Agriculture. pp 19.

14.Pulleman, M.M., Six, J., Van Breemen, N. and Jongmans, A.G. (2005). Soil organic matter distribution and microaggregate characteristics as affected by agricultural management and earthworm activity. European Journl of Soil Science. 56:453-467.

15.Shukla. A.K., Tiwari, P.K., Pakhare, A. and Prakash, C. (2016). Zinc and iron in soil, plant and human health. Indian Journal of Fertilizers. 12:133-149.

16.Singh, S. and Kumar, P. (2012). Soil fertility status of vegetables growing area of Varanasi and pulses growing area of Mirzapur. Journal of the Indian Society of Soil Science. 60:233-236.

17.Singh, S.K., Dey, P., Sharma, P.K., Singh, Y.V., Latare, A.M., Singh, C.M., Kumar, D., Kumar, O., Yadav, S.N. and Verma, S.S. (2016a). Primary and cationic micronutrients status in few districts of eastern Uttar Pradesh. Journal of the Indian Society of Soil Science. 64:319-332.

18.Singh, Y.V., Singh, S.K., Sahi, S.K., Verma, S.K., Yadav, R.N. and Singh, P.K. (2016b). Evaluation of soil fertility status from Milkipur village, Araziline Block, Varanasi district Uttar Pradesh in relation to soil characteristics. Journal of Pure and Applied Microbiology. 10:1455-1461.

19.Subbiah, B.V. and Asija, G.L. (1956). A rapid procedure for determination of available nitrogen in soil. Current Science. 25:259-260.

20.Tiwari, R.C., Agarwal, H.P., Maurya, B.R. and Narayan, D. (2003). Organic matter recycling and enrichment. Department of Soil Science and Agricultural Chemistry, Institute of Agricultural Sciences, Banaras Hindu University Varanasi. Final Report of the Research Project, Submitted to ICAR (NATP), New Delhi. pp 36-41.

21.Walkley, A. and Black, C.A. (1934). An examination of the Degtjareff method for determining soil organic matter, and a proposed modification of the chromic acid titration method. Soil Science. 37:29-38.

22.Williams, C.H. and Steinberg, A. (1959). Soil sulphur fractions as chemical indices of available sulphur in some Australian soils. Australian Journal of Agricultural Research. 10: 340-352. 